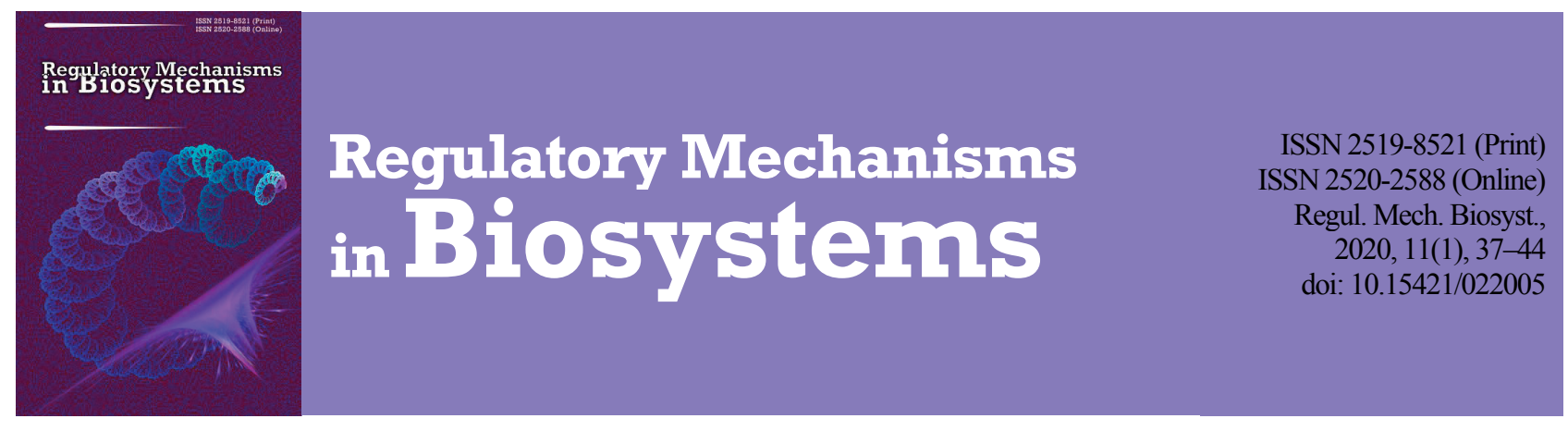

\title{
Polychlorinated biphenyls: Hazardous properties and environmentally sound management in Ukraine
}

\author{
N. O. Ryzhenko*, O. I. Bondar*, V. V. Chetverykov**, Y. O. Fedorenko* \\ *State Ecological Academy of Post-Graduate Education and Management, Kyiv, Ukraine \\ **The Gas Institute, National Academy of Sciences of Ukraine, Kyiv, Ukraine
}

Article info

Received 10.01.2020

Received in revised form 03.02 .2020

Accepted 04.02.2020

State Ecological Academy

of Post-Graduate Education

and Management,

Vasylya Lypkivskogo st., 35,

Kyiv, 03035, Ukraine.

Tel.: +38-095-888-52-05.

E-mail:alsko2011@ukr.net

The Gas Institute,

National Academy

of Sciences of Ukraine,

Degtyarivska st., 39

Kyiv, 03113, Ukraine.

Tel.: +38-050-741-14-98

E-mail:

chvvingas@gmail.com
Ryzhenko, N. O., Bondar, O. I., Chetverykov, V. V., \& Fedorenko, Y. O. (2020). Polychlorinated biphenyls: Hazardous properties and environmentally sound management in Ukraine. Regulatory Mechanisms in Biosystems, 11(1), 37-44. doi:10.15421/022005

Polychlorinated biphenyls are one of the most dangerous compounds for human health and the environment and are included to Annex C of the Stockholm Convention on Persistent Organic Pollutants. Since Ukraine joined the Stockholm Convention in 2007, the National Implementation Plan of the Stockholm Convention provides the environmentally sound disposal of polychlorinated biphenyls, as well as creation of a monitoring system and sharing information about toxicants. Polychlorinated biphenyls' have fire resistance, low volatility and stability. Therefore, these substances have been widely used in industry, but on the other hand, they are a problem for the environment. The main hazardous properties of polychlorinated biphenyls are bioaccumulation, stability in the environment, the possibility of formation in accidents (especially in fires) of extremely persistent and toxic aromatic compounds, such as dioxins and furans. Toxic responses to polychlorinated biphenyls are: acute lethality; body weight loss; carcinogenesis; dermal toxicity; fatty liver; genotoxicity; hepatomegaly; immunosuppressive effects; neurotoxicity; porphyria; reproductive and developmental toxicity; thymic atrophy; thyroid hormone-level alterations. The most likely risks of polychlorinated biphenyls contamination in Ukraine are in the areas of operation, repair or storage of electrical equipment. According to quantity, the leading regions for accumulated polychlorinated biphenyls in Ukraine, are Dnipropetrovsk (459 tons), Volyn (280 tons) and Kyiv regions (255 tons). A comprehensive approach to reducing the risk of polychlorinated biphenyls for human health and the environment involves the improvement of the regulatory framework for managing in all stages of "life cycle". Obtaining complete and accurate information on the volumes and forms of polychlorinated biphenyls accumulation and creation of modern effective technological support for polychlorinated biphenyls' degradation are a necessary part of environmentally sound management of polychlorinated biphenyls in Ukraine. The "Polychlorinated Biphenyls Database in Ukraine" information system (2017) was created as a National Polychlorinated Biphenyls Registry in Ukraine. It was designed to systematize, structure, and analyze the large amount of information collected during the inventorising of polychlorinated biphenyls. The best technology of polychlorinated biphenyls degradation must not only provides a high degree of polychlorinated biphenyls' destruction, but also not lead to the formation of new toxic compounds.

Keywords: PCB; toxicity; environmentally sound management; dangerous properties.

\section{Introduction}

Polychlorinated biphenyls (PCBs) are among the most dangerous compounds for human health and environment. These pollutants are included to Annex C of the Stockholm Convention on Persistent Organic Pollutants (POPs) and are formed of aromatic compounds formed in such a manner that the hydrogen atoms on the biphenyl molecule (two benzene rings bonded together by a single carbon-carbon bond) may be replaced by up to ten chlorine atoms. Ukraine ratified the Stockholm Convention on Persistent Organic Pollutants on April 18, 2007. The Ukrainian National Implementation Plan of the Stockholm Convention provides: the environmentally sound disposal of polychlorinated biphenyls; creation of a monitoring system and sharing information about toxicants; developing the technologies for cleaning transformers from PCBs; identification of areas contaminated by PCBs, etc. PCBs have never been produced in Ukraine, but, as in other industrialized countries, have been widely used in various industries. PCBs were used extensively during the 1950s to 1970 s, mostly in industrial applications (such as coolants and insulating fluids) and as additives and sealants in building materials. After the 1970s, the production and use of PCBs was gradually restricted in many countries, and global emissions started to decrease. However, the decline in emissions lags strongly behind the rate of phase-out of production, because stocks of products in-use and materials continue to release PCBs to the atmosphere throughout their lifetime. Waste dumps, decommissioning sites, as well as in-use stocks represent the primary sources of today (Diamond et al., 2010; Gasic et al., 2010; Bogdal et al., 2014; Carlsson et al., 2018). There are 209 individual PCB congeners, differing in the number and position of chlorine atoms in the molecule, having the common formula. PCBs may be unintentionally formed and released from the different source categories, including: open burning of waste, including burning of landfill sites; thermal processes in the metallurgical industry; combustion sources; fossil fuel-fired utility and industrial boilers; firing installations for wood and other biomass fuels; waste oil refineries and others. According to the World Health Organization, the main pathways for PCBs to enter the environment are: evaporation from plasticizers; allocation during incineration of domestic and industrial waste, as well as during the ignition of transformers, capacitors and other industrial equipment in which PCBs are used; industrial waste leakage; removal of PCBs to landfills and aeration fields; other uncontrolled paths. On the one hand, due to their fire resistance, low volatility and stability, PCBs have been widely used in industry, but on the other hand, they are a problem for the environment. The main hazardous properties of PCBs are: the bioaccumulation, stability in the environment, the possibility of formation the extremely persistent and toxic aromatic compounds such as dioxins and furans during accidents (fires). PCBs are rarely associated with immediate risk. However, PCBs accu- 
mulate in the human body and are found in very small quantities over many years.

\section{Toxicity for humans}

Depending on the number of chlorine atoms in the molecule, PCBs have different physical, chemical, and toxic properties. About 70 of all congeners were used in technical mixtures, and 10 of these congeners are the most important for hazard assessment. Dioxin-like congeners are potentially dangerous and have the similar toxic properties as dioxins and furans. Dioxin-like PCBs include: four non-ortho-substituted (planar) PCBs (PCBs 77, 81, 126, 169) and eight mono-substituted PCBs (PCBs 105, 114,118, 123, 156, 167, 189). Ortho-unsubstituted and monoortho-substituted PCBs have the similar mechanism of influence on living organisms as 2,3,7,8-tetrachlorodibenzo-p-dioxin (2,3,7,8TCDD) (Leonards, 1997). Chronic entry to animals' organisms of different doses of PCBs leads to dysfunction and destruction of many organs. The most pronounced changes are demonstrated by the induction of the activity of microsomal enzymes, and, above all, mixedfunction oxidases, which play a leading role in the disinfection of toxic substances registered in the liver. The International Agency for Research on Cancer has classified dioxin-like PCBs as probable human carcinogens. In general, dioxin-like effects include a wide variety of sexual, strain, age, and species-specific effects, including carcinogenicity, immunotoxicity, reproductive or developmental toxicity, hepatotoxicity, neurotoxicity, weight loss (Dianyi, 2014). Toxic responses of PCBs are presented in Figure 1.

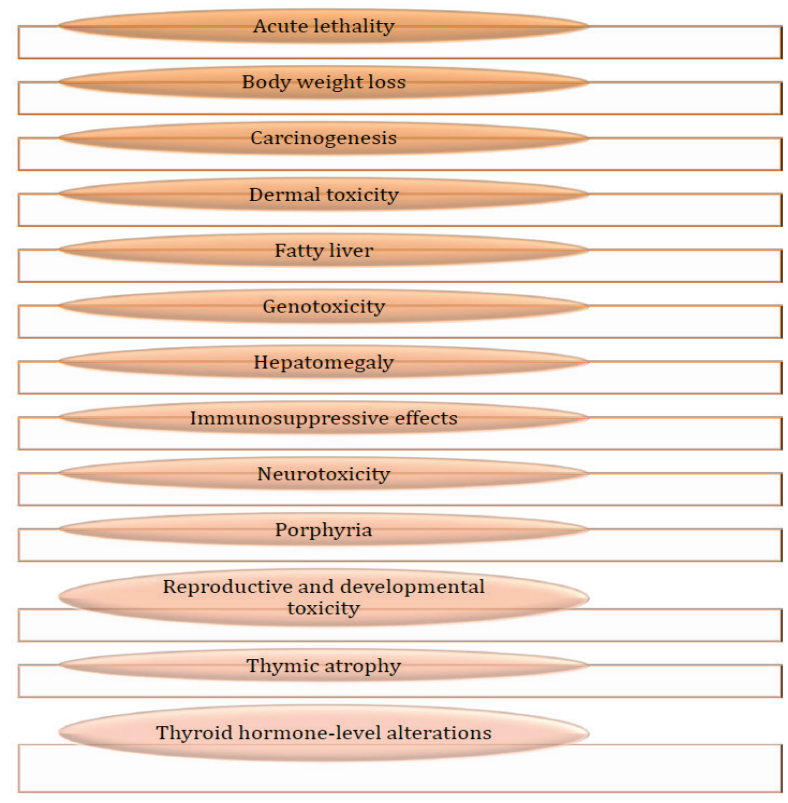

Fig. 1. Toxic responses of PCBs

Current epidemiological studies also propose a connection between the effects of PCBs and the occurrence of diabetes (type 2, Fig. 2). Some of the PCBs' congeners have also an antiestrogenic effect. The higher chlorinated PCBs (PCB 156,180,194) were linked with increased risk of non-Hodgkin's lymphoma development (De Roos et al., 2005; Faroon \& Ruiz, 2011). Hardell et al. (2004) found that the concentration of PCBs in the blood of mothers of patients with testicular cancer was higher than in control; studies also maintain the hypothesis of fetal origin of testicular cancer (Hardell et al., 2003; Faroon \& Ruiz, 2011).

Commercial PCBs mixtures cause a wide range of toxic reactions that depend on a number of factors, such as: the dose of PCBs; chlorine content; age and gender of living organism; species variety; the path of PCBs action; duration of PCBs influence; environmental conditions.

There is a high risk of poisoning from PCBs pollution caused by fire. Dioxins and furans (polychlorinated dibenzodioxins, dioxins, polychlorinated dibenzofurans, and furans) may form and release on heating of PCBs as a result of incomplete combustion or chemical reactions.
Human exposure to PCBs can be caused by contamination of food or water, inhalation of $\mathrm{PCB}$ vapour in the air and through direct skin contact. In the human organism, the ratio of accumulated PCBs average concentration in brain- liver- fat tissues is 1-3.5-81 (Kutsenko, 2003). Victims of the Yu-Cheng accident (the one of the most famous instances in the world of PCB contamination, 1979) had $80 \mathrm{ng} / \mathrm{g}$ (total PCBs) in the brain, and $11 \mu \mathrm{g} / \mathrm{g}$ in fat tissue accordingly (Chen \& Hsu, 1986).

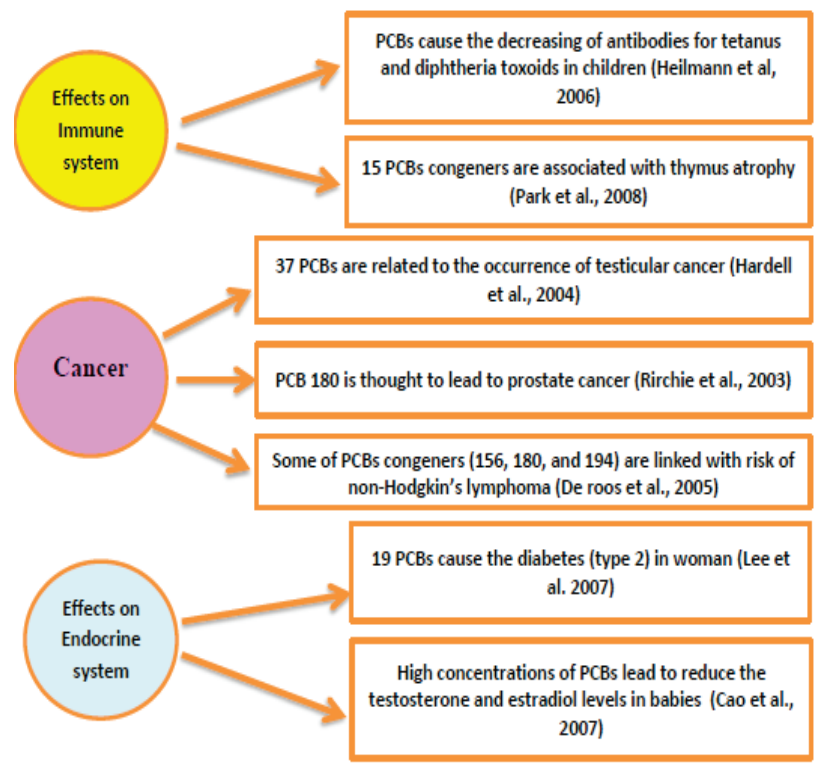

Fig. 2. Some effects of PCBs influence on human health

According to the Commission Regulation EU (No 1259/2011 of 2 December 2011) amending Regulation (EC) No 1881/2006 as regards maximum levels for dioxins, dioxin-like PCBs and non-dioxinlike PCBs in foodstuffs, the maximum levels for PCDD/PCDF, sum of PCDD/PCDF and dioxin-like PCBs and sums of 6 non-dioxin-like (indicator) PCBs (PCBs 28, PCBs 52, PCBs 101, PCBs 138, PCBs 153 and PCBs 180) were established based on the revised criteria. Each congener of dioxins or Dioxin-Like-PCBs exhibits a different level of toxicity. In order to be able to sum up the toxicity of these different congeners, the concept of toxic equivalency factors (TEFs) was introduced to facilitate risk assessment and regulatory control. As a result the analytical results relating to all the individual dioxin and dioxin-like PCB congeners of toxicological concern are expressed in terms of a quantifiable unit, namely the TCDD toxic equivalent (TEQ, Fig. 3). Maximum levels have been established taking into account recent occurrence data compiled in the scientific report "Results of the monitoring of non-dioxin-like PCBs in food and feed" accomplished by European Food Safety Authority in 2010. According to "Regulation of maximum levels for certain contaminants in food" (No 774/23306, the order of Health Ministry No 368 13.05.2013), maximum levels of PCBs in foodstuffs in Ukraine are the same as that presented by Commission Regulation (EU) No 1259/2011 of 2 December 2011.

\section{Toxicity for biota}

Chronic toxicity has been observed in fish, birds, mammals and others. Individual PCBs congeners can influence through different mechanisms and have various toxic possibilities (Safe, 1984; Strang et al., 1984; Safe, 1994; Seegal, 1996). The general impacts of PCBs on the environment and biota are due not only to the individual components of the mixtures (for example, Sovol or Sovtol), but also the interactions among the PCBs' congeners present and between the PCBs and the other compounds. Risk assessments of PCBs, therefore, require information on the levels of individual PCBs' congeners present in the PCB mixture and data on their interactions (Farrington, 2001). Toxicity for several PCBs' congeners for fish, birds, and mammals is presented in the Table 1.

According to Nyska et al. (2004), PCB126 has a harmful effect on the pancreas, including the formation of carcinoma. PCB126 also resulted in increase of bronchiolar metaplasia of the alveolar epithelium, as 
reported by Brix et al. (2004). Moreover, exposure to PCB126 increased the incidences and severity of neoplastic and nonneoplastic lesions in the lung. As Cromwell et al. (2007) and Cumming et al. (2005) reported, PCB77 exposure changed aspects of maternal-offspring interaction in rodents.

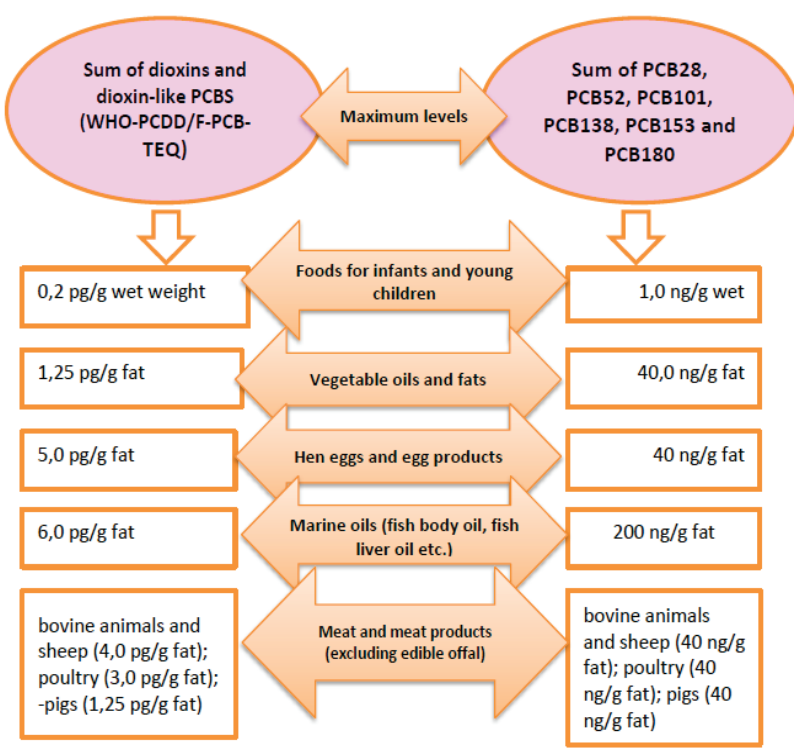

Fig. 3. Maximum levels of PCBs in foodstuffs

Sovtol and Sovol are industrial mixtures containing PCBs and used in Ukraine and other countries. $\mathrm{LD}_{50}$ of Sovtol for white rats was $7318.9 \mathrm{mg} / \mathrm{kg} ; \mathrm{LD}_{16}$ was $4607.4 \mathrm{mg} / \mathrm{kg} ; \mathrm{LD}_{84}$ was $11626.4 \mathrm{mg} / \mathrm{kg}$ (Feshin et al., 2006). $\mathrm{LD}_{50}$ 2,3,7,8-TCDD was $0.045 \mathrm{mg} / \mathrm{kg}$; $\mathrm{LD}_{16}$ was
$0.018 \mathrm{mg} / \mathrm{kg}$, and $\mathrm{LD}_{84}$ was $0.062 \mathrm{mg} / \mathrm{kg}$. Therefore, Sovol had lower acute toxicity than $2,3,7,8$-TCDD. However, in groups of white rats receiving maximum doses of Sovtol, the death of the stock was observed within the first three weeks. Five to six days after Sovtol's ingestion, the first signs of intoxication of animals were admitted, for example, decreased motor activity, "sloppy appearance", reluctant consumption of feed and water (Feshin et al., 2005). Further, the deepening symptoms of intoxication were observed. There was diarrhea, nervous system damage, regularity of neck muscles, impaired movement coordination, attenuation of reflexes to external stimuli (light, sound). With the introduction of Sovtol at doses of 2000 and $3000 \mathrm{mg} / \mathrm{kg}$, symptoms of lung damage (difficulty in breathing), nosebleeds, cataracts, blindness, decreased body weight gain was observed. The first clinical signs of poisoning in birds from Sovtol were admitted as early as three days after its use: suppression of the general condition of chickens, squatting feather cover, hypodynamia, reduced use of water and feed. One of the most prominent signs of intoxication was the progressive decline in body weight. In general, Sovtol for acute toxicity in oral admission to white rats was attributed to low-risk substances (IV class of danger, $\mathrm{LD}_{50}$ $7318.9 \mathrm{mg} / \mathrm{kg}$ ), and for chickens to moderately dangerous substances (III class of danger, $\mathrm{LD}_{50} 2357.4 \mathrm{mg} / \mathrm{kg}$ ) (Feshin et al., 2005, 2006). PCBs levels in the tissues of chickens after Sovtol ingestion were significantly lower than in the tissues of chicks, indicating that the PCB was partially eliminated from the body of chickens by egg biomass. In addition, PCBs were found to have a negative effect on the formation of post-vaccine immunity in birds. The toxic effects of PCBs in birds are presented in Figure 4 (Farrington, 2001). The concentration of more than $0,5 \mu \mathrm{g} / \mathrm{L}$ of PCBs affect growth and reproduction of algae and zooplankton. Exposure to PCBs at a level more than $25 \mathrm{mg} / \mathrm{kg}$ causes changes in reproductive system and growth of macroinvertebrates (Farrington, 2001).

Table 1

TCDD toxicity equivalency factors (TEFs) for several dioxin-like PCB congeners for fish, birds, and mammals

\begin{tabular}{lccccccc}
\hline Animal & $\begin{array}{c}3,4,4^{\prime}, 5- \\
\text { Tetrachlorobiphenyl } \\
\text { (PCB 81) }\end{array}$ & $\begin{array}{c}2,3^{\prime}, 4,4^{\prime}, 5- \\
\text { Pentachlorobiphenyl } \\
\text { (PCB 118) }\end{array}$ & $\begin{array}{c}3,3^{\prime}, 4,4^{\prime}, 5- \\
\text { Pentachlorobiphenyl } \\
\text { (PCB 126) }\end{array}$ & $\begin{array}{c}2,3,3^{\prime}, 4,4^{\prime}, 5^{\prime}- \\
\text { Hexachlorobiphenyl } \\
\text { (PCB 157) }\end{array}$ & $\begin{array}{c}2,3^{\prime}, 4,4^{\prime}, 5,5^{\prime}- \\
\text { Hexachlorobiphenyl } \\
\text { (PCB 167) }\end{array}$ & $\begin{array}{c}3,3^{\prime}, 4,4^{\prime}, 5,5^{\prime}- \\
\text { Hexachlorobiphenyl } \\
\text { (PCB 169) }\end{array}$ & $\begin{array}{c}2,3,3^{\prime}, 4,4^{\prime}, 5,5^{\prime}- \\
\text { Heptachlorobiphenyl } \\
\text { (PCB 189) }\end{array}$ \\
\hline Fish & 0.0005 & $<0.000005$ & 0.005 & $<0.000005$ & $<0.000005$ & 0.00005 & $<0.000005$ \\
Birds & 0.1 & 0.00001 & 0.1 & 0.0001 & 0.00001 & 0.001 & 0.00001 \\
Mammals & 0.0001 & 0.0001 & 0.1 & 0.0005 & 0.00001 & 0.01 & 0.0001 \\
\hline
\end{tabular}

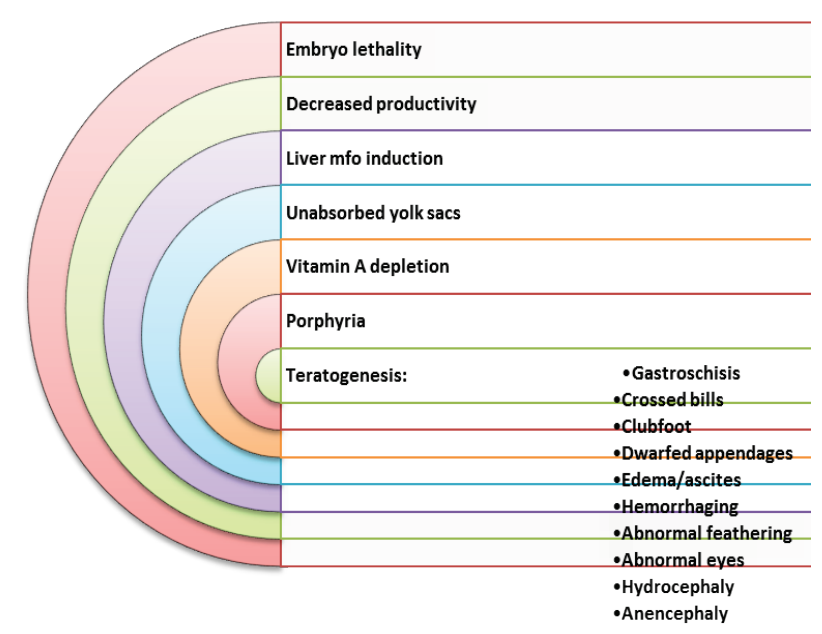

Fig. 4. Toxic effects of PCBs observed in birds

Monkeys and minks are highly sensitive to PCBs. Monkeys have swelling, baldness, and blackheads - the signs closest to the symptoms that people experience with PCBs' poisoning. Young fish and higher vertebrates have similar observed toxicity and histopathological damage caused by PCBs. The main toxicity effects detected are: decreased food intake, syndrome of exhaustion, lesions in the epithelial and lymphoma. Fish are characterized by high variety of species sensitivity to PCBs. Fish preferentially bioaccumulate highly chlorinated penta-, hexa-, and hepta-chlorinated biphenyls, but not deca-chlorinated biphenyls (Walker \& Peterson, 1994). Freshwater salmon species, especially lake and rainbow trout, are the most sensitive fish species to the impact of PCBs (Farrington, 2001). Water-based concentration effect levels are not appropriate for evaluating the potential risk. To evaluate the dangers and risks of PCBs, threshold doses and toxic effects must be estimated. NOEL and LOEL of PCBs to aquatic mammals were suggested by Kannan et al. (2000) (Fig. 5).

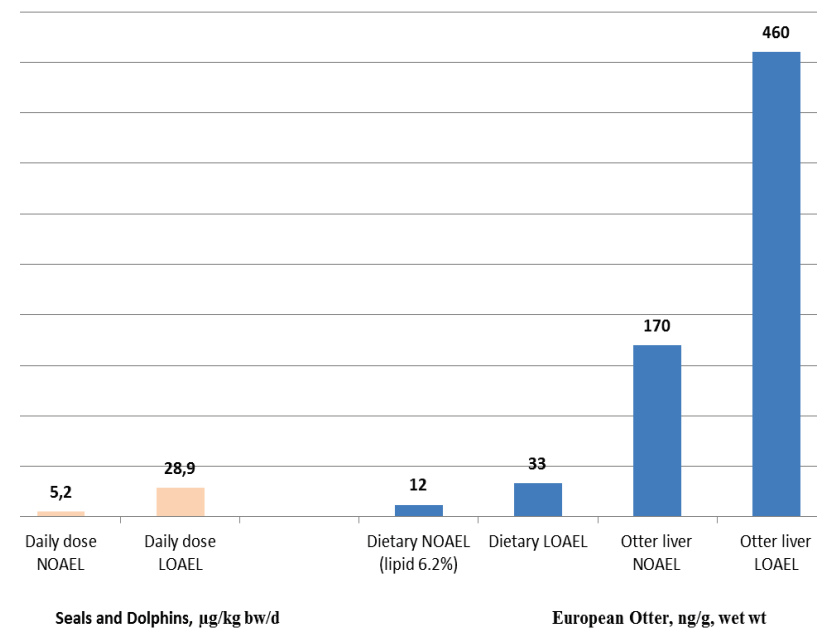

Fig. 5. NOAEL and LOAEL to aquatic mammals for total PCBs 


\section{Environmental hazards}

The most dangerous properties of PCBs for the environment are a persistent, high bioaccumulative availability, the ability to carry over long distances. Photodegradation of PCBs occurs in very limited quantities, the compounds are not hydrolyzed and oxidized, and they are resistant to acids and alkalis and high temperature. PCBs are slow to biodegrade in the environment in comparison with many other organic chemicals and are generally persistent in all media. Factors affecting the PCBs transformation rate in the environment: $\mathrm{PCB}$ concentration, bioavailability, inhibitors, temperature. The less-chlorinated congeners are more water soluble, more volatile, and more likely to biodegrade. Higher-chlorinated PCBs are often more resistant to degradation and volatilization and sorb more strongly to particulate matter. Some of these more-chlorinated PCBs tend to bioaccumulate to greater concentrations in tissues of animals than do lower-molecular-weight PCBs. Specific structures of higher-molecularweight congeners make them susceptible to metabolism by enzymes. Therefore these congeners are taken up by fish, crustaceans, birds, and mammals (Farrington, 2001). Anaerobic conditions are preferable for the decomposition of more chlorinated PCBs and aerobic conditions for less chlorinated PCBs (Tiedje et al., 1993). PCBs have relatively low water solubility and low vapour pressures which allow them to partition between water and the atmosphere. Along with organochlorine pesticides, PCBs are the most common water pollutants in natural water. Contamination of bottom sediment by PCBs can cause permanent local contamination of aquatic organisms for a long time (up to several years). It is believed that the oceans are the largest sinks of PCBs. Biomagnification in hydrobiota and other living organisms is one of the main criteria of dangerous risks assessment of PCBs. Biomagnification factors of Alewife and Herring Gull eggs are presented in Figure 6 (Hoffman et al., 1996).

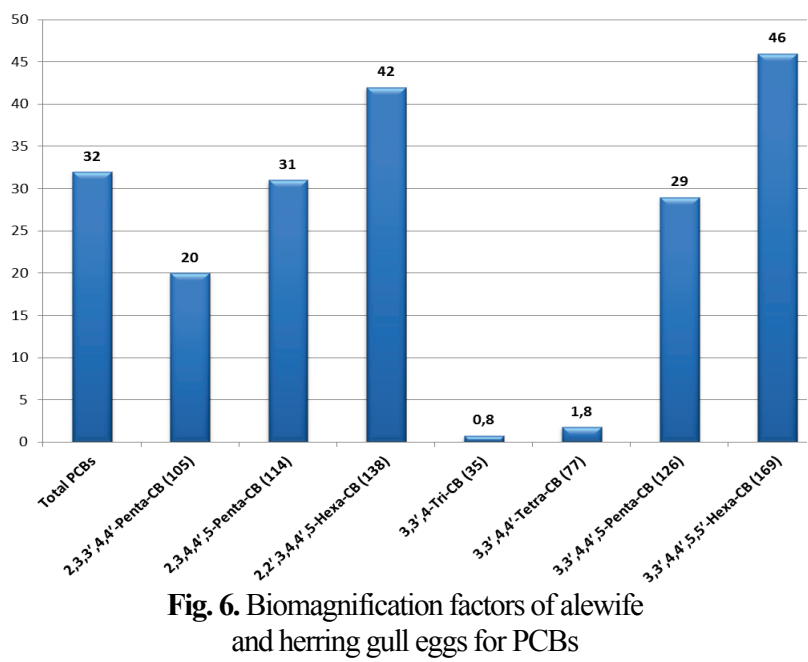

High-chlorinated PCB congeners are equally characterized by significant bioaccumulation in marine (ocean) fish. For example, PCBs congeners were found in certain fish species in Aleutian Islands, Alaska. The most prevalent congeners expressed as percent of total PCBs were congeners PCB164+PCB163+PCB138, PCB153, PCB180, PCB90+PCB101, PCB187, PCB118, PCB132, and PCB170 (Hardell et al., 2010). Average PCBs concentrations in fish were (ng $/ \mathrm{kg}$ raw weight): 135 - for Oncorhynchus nerka; 124 - for Gadus macrocephalus; 285 for Lepidopsetta bilineata; 158 - for Hippoglossoides elassodon; 113 for Salvelinus malma; 151 - for Myoxocephalus polyacanthocephalus; 104 - for Hexagrammos lagocephalus.

In many cases, the major sources of PCBs in the environment are located nearby at pollution sites. However, some PCBs entered ecosystems from distant sources after air currents traveled thousands or even tens of thousands kilometers. PCBs can be carried over long distances by air currents as they are volatile in air or easily attached to atmospheric dust particles. Though, the pollutants are not volatile enough to stay in the atmosphere, they travel with air currents for short and long distances, and then when the temperature drops or the rain begins, the PCBs from the air enter the surface of the soil. PCBs remain on the soil surface only for a short time, and then evaporate again into the air, moving between the air and the soil surface. This phenomenon was called the "effect of jumping grasshopper". Low-chlorinated PCBs are more volatile and can be transported in the atmosphere over 20,000 km (Carlsson et al., 2018). Atmospheric long-range transport is still considered to be a major route for the global environmental distribution of PCBs into remote areas. Even today, transport of contaminated air masses to the Arctic still occurs from regions in industrialized countries, where PCBs are still emitted from various sources (Hung et al., 2016). Thereafter, PCBs "stick" to the surface of organic particles in the water column, which leads to their possible deposition and accumulation in the sediment. The highest concentrations of PCBs are usually found in organic matter. PCBs are considered to exist in three phases in the sediment and overlying water: freely dissolved, associated with dissolved organic carbon (DOC), and sorbed to particles (Farrington, 2001). Deposition processes and snow ice interactions of PCBs have been a research focus in the Canadian Arctic for many years (Macdonal \& Bewers, 1996). In 2012, the average concentration of 29 PCBs in snow was $256 \pm 177 \mathrm{pg} / \mathrm{L}$, although the two new snow layers sampled in May showed higher concentrations of 545 and $611 \mathrm{pg} / \mathrm{L}$ (Carlsson et al., 2018). In this regard, the average concentration in the snow cover was $185 \pm$ $85 \mathrm{pg} / \mathrm{L}$, which is significantly higher than the concentration of PCBs in the surface layer of seawater. Therefore, the preservation of volatile PCBs congeners from the lower atmosphere layer by snow cover is effective.

According to the forecast model (Wöhrnschimmel et al., 2013), the effect of the changing climate on PCBs is not only their enhanced volatilization from ice-free surface seawater but also enhanced storage of the compounds in the areas of the Arctic Ocean that are covered by ice. The contribution of precipitation to the substance cycling will also increase. The total environmental residence time (i.e. persistence) of PCB153 will be reduced by $40 \%$ in the 2090 s compared to the 1990 s, mostly due to increased biodegradation in soil and water (Carlsson et al., 2018).

Today, the main path of PCBs global spreading is the atmospheric migration. Precipitation plays an important role in their spread in both terrestrial and marine areas on Earth. Currently, secondary PCBs sources (accumulated in environmental reservoirs, such as sediments, water, soil, snow, and ice) are becoming more important than primary sources. Climate change is likely to increase the weight of secondary PCBs. Accumulated PCBs in ice can be released into the water (oceans, rivers, precipitation etc.), and then PCBs can be up-taken by living organisms as well as being able to migrate in biogeochemical cycles and along the food chain (Carlsson et al., 2018).

According to the research of Halse et. al (2011), the highest atmospheric concentrations of PCB7 are present in Central and Eastern Europe, where levels higher than $500 \mathrm{pg} / \mathrm{m}^{3}$ can occur and indicate the presence of 'hot spots' areas. The concentrations in Arctic areas are generally in the range $<5-30 \mathrm{pg} / \mathrm{m}^{3}$ (Hung et al., 2016). In Ukraine, PCBs content has been detected in the flue gases of factories at thermal treatment of municipal solid waste $\left(460-670 \mathrm{ng} / \mathrm{m}^{2}\right)$. In the natural water of the Dnieper basin (Kyiv, Dnipro, Zaporizhia, Mykolaiv, Nikopol) PCBs content averages $41 \mathrm{ng} / \mathrm{dm}^{3}$ (Moklachuk et al., 2017). Khahula et al. (2018) have found PCBs in soil from sites near storage of waste with obsolete pesticides (Stavishche district, Kyiv region). In 0-20 cm soil layer, PCBs were determined in concentration of $0.04 \mathrm{mg} / \mathrm{kg}$ at a distance of $50 \mathrm{~m}$ from the waste storage; $0.37 \mathrm{mg} / \mathrm{kg}$ of PCBs at a distance of $5 \mathrm{~m}$ from the waste storage. In soil samples $(20-40 \mathrm{~cm})$, minimum PCBs values $(0.01 \mathrm{mg} / \mathrm{kg})$ were detected at a distance of $50 \mathrm{~m}$ from the waste storage, maximum values $(0.10 \mathrm{mg} / \mathrm{kg})$ were found at a distance of $5 \mathrm{~m}$ near waste storage. Khahula et al. (2018) consider, that PCBs concentration near waste storage could be appear as a result of past use of pesticides which included PCBs.

\section{Environmentally sound management in Ukraine}

The identification and primary accounting of equipment with concentrated PCBs in Ukraine is carried out in accordance with the indicative lists of standard equipment given in the "Methodological Recommendations for Detection and Identification of Polychlorinated Biphenyls (PCBs)" approved by the Ministry of Ecology and Natural Resources of Ukraine in 2003. 
Distribution of transformers containing PCBs in administrative units, as a result of inventory, $\mathrm{pc} / \mathrm{kg}$ PCBs.

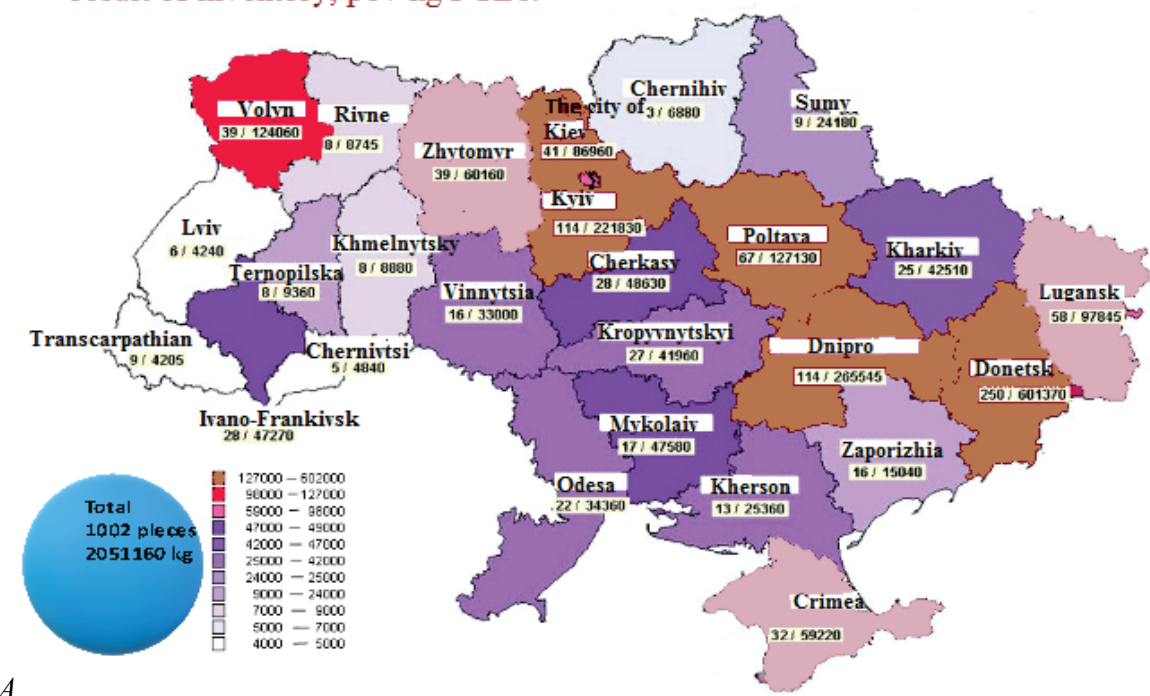

$A$

Distribution of synthetic liquids containing PCBs in administrative units, as a result of the inventory, pcs / kg PCBs.

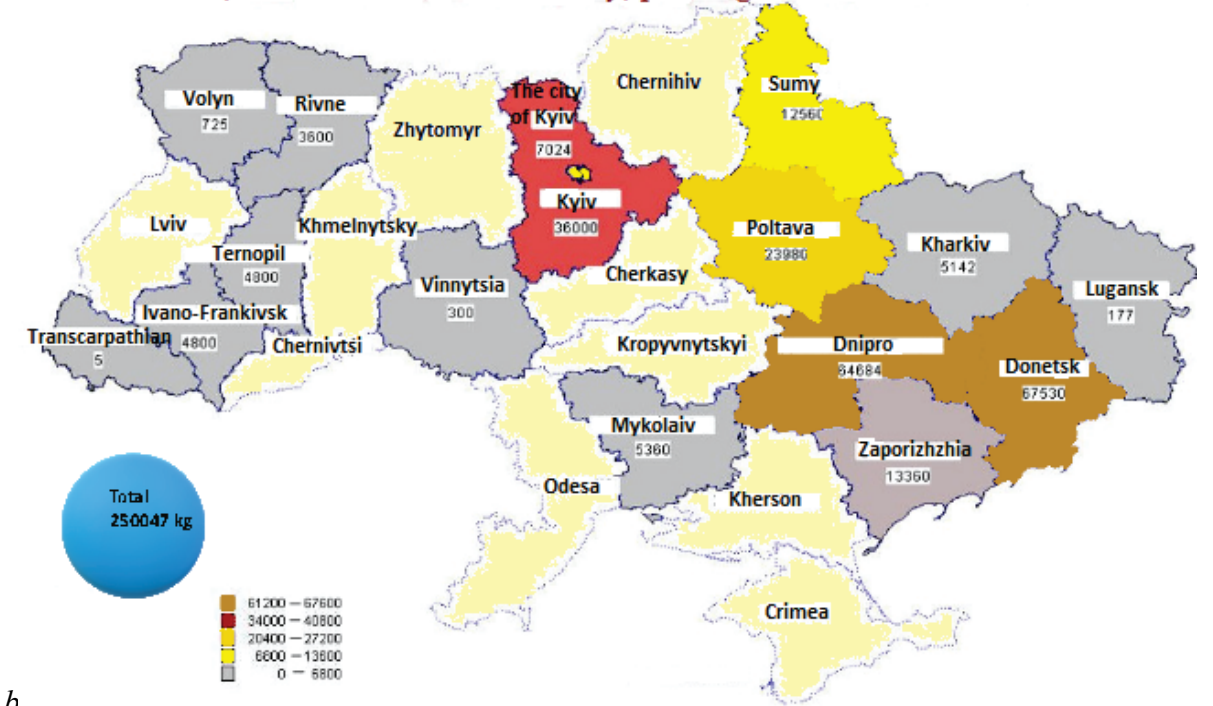

The distribution of capacitors containing PCBs in administrative units, resulting from the inventory, pcs / $\mathrm{kg}$ PCBs.

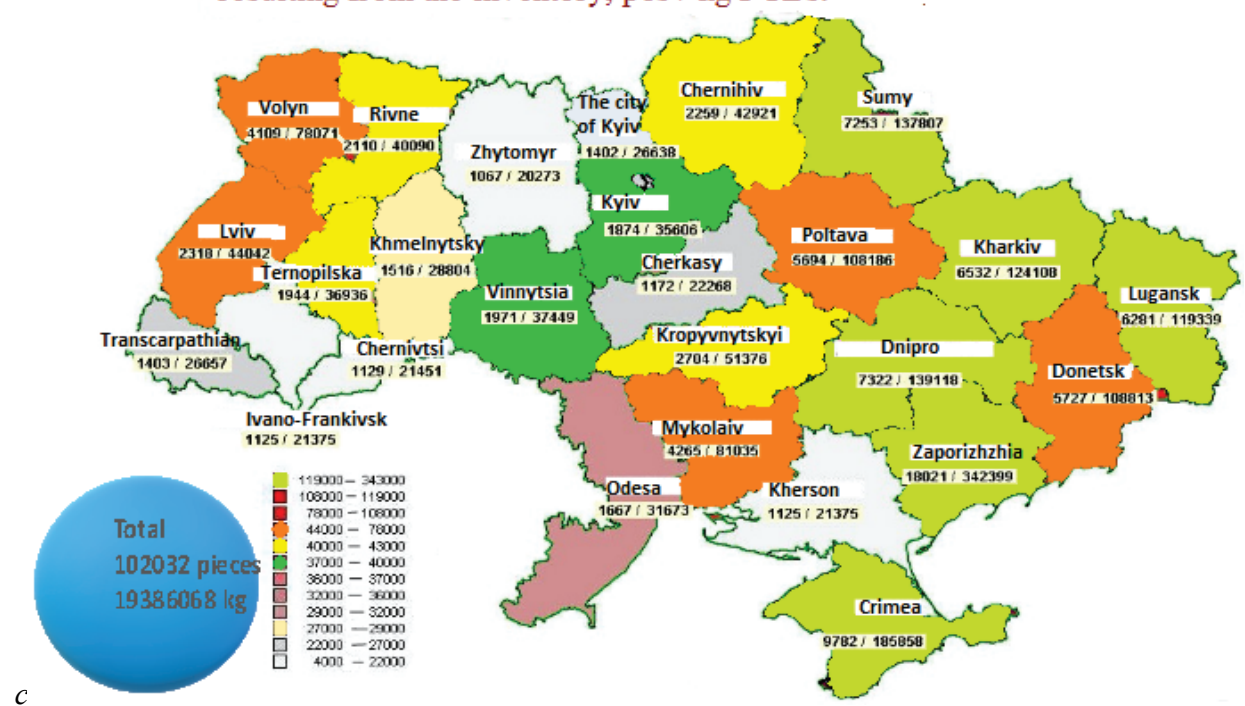

Fig. 7. Results of the previous inventories in Ukraine: $a$ - distribution of transformers with PCBs content; $b$-distribution of synthetic liquids containing PCBs; $c$-distribution of capacitors with PCBs content 


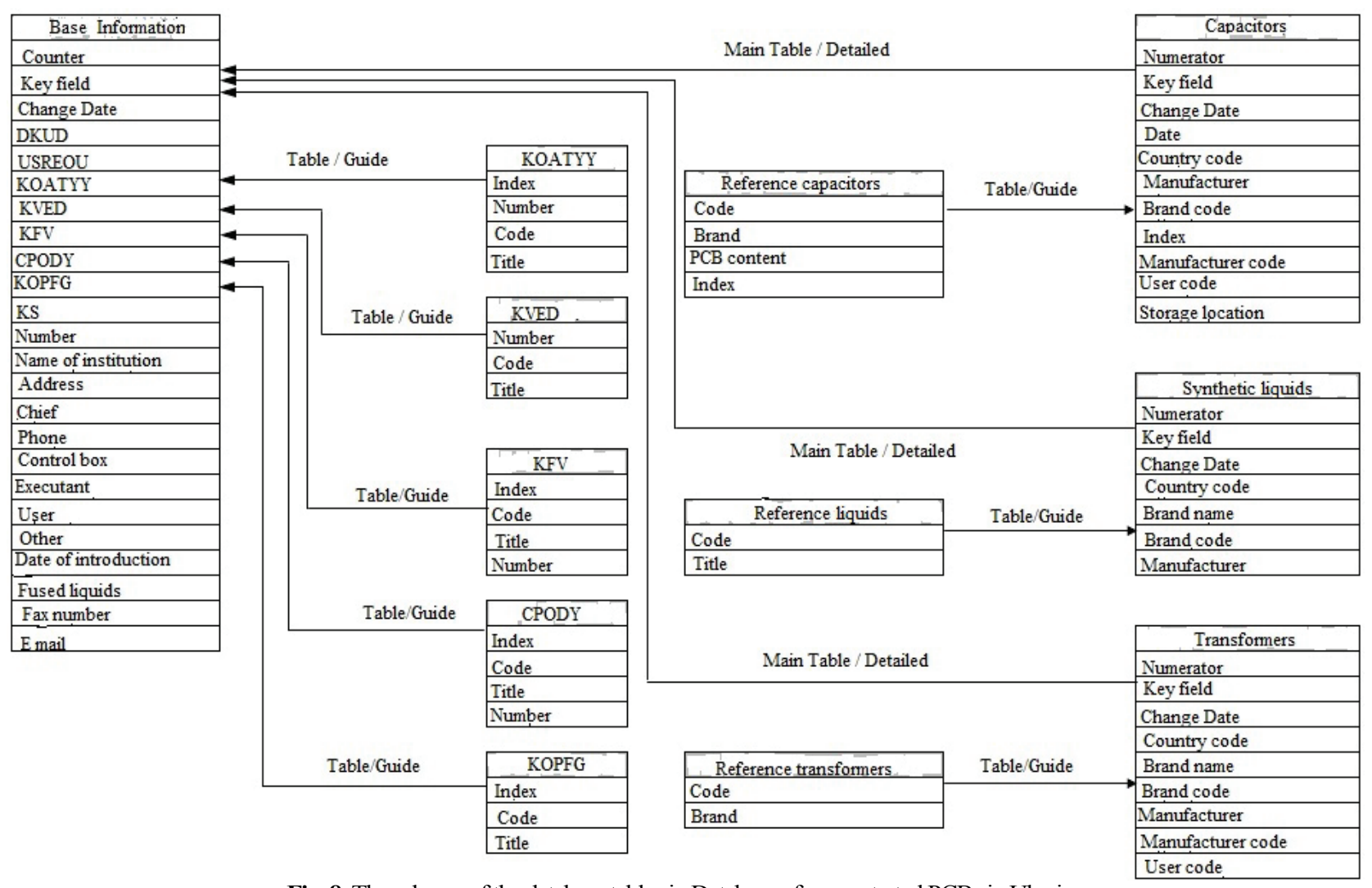

Fig. 8. The schema of the database tables in Database of concentrated PCBs in Ukraine

Identification and primary accounting of PCBs waste in Ukraine is carried out in accordance with the current waste accounting system. Chemical analytical studies on the presence of PCBs contamination in Ukraine are realized in two stages. The first stage is a screening test for the presence of chlorine compounds, and the second stage is the identification of PCB compounds and their quantification by chromatography methods (EN 12766-1:2000, IDT; EN 12766-2:2001, IDT; IEC 61619:1997, IDT). Since September 2019, the above mentioned standards have come into effect as State Standards of Ukraine. The most common use for screening tests is Clor-N-Oil 50 ppm (CL-050-SG) sets with L2000 PCV/Chloride analyzer, as well as SM-TCPs-KIT. According to analytical materials of the GEF-UNIDO Project on PCB management in Ukraine "Environmentally sound management and final disposal of polychlorinated biphenyls (PCBs) in Ukraine", previous PCBs inventories (2003-2007) in Ukraine have shown that almost all of their accumulation falls on electrical equipment. Therefore, the most likely risks of PCB contamination are in the areas of operation, repair or storage of electrical equipment (Mykhailenko et al., 2018). In obedience to the data of above mentioned Project, leaders of accumulated PCB quantities are Dnipropetrovsk (459 tons), Volyn (280 tons) and Kyivsk regions (255 tons, Fig. 7). The total mass of PCBs, which are present in equipment and stored separately on objects in Ukraine, according to the results of the initial inventory, is estimated as 5,000 tons.

The "PCBs Database in Ukraine" information system was created as a National PCBs Registry in Ukraine. "PCBs Database in Ukraine" was designed to systematize, structure, and analyze the large amount of information collected during PCBs inventory (Chetverykov et al., 2018) (Fig. 8). Since 2017, the National PCBs Registry has been supplemented with databases of contaminated PCB-containing equipment.

The set of operations to be performed in the removal of PCBs-containing waste is determined by information such as: the aggregate state of the waste; the PCBs content in the waste; the presence in the waste of components requiring specific methods of disposal; the need or possibility of reuse of some waste components; etc. (Kummling et al., 1997; Rahuman et al., 2000; Weber, 2004; Chetverykov et al., 2018). The choice of PCBs destruction technology should be made taking into account the toxic properties of $\mathrm{PCBs}$, especially, their persistence in the environment, and ability to produce toxic compounds during heating (Addink
\& Olie, 1995; Huang, \& Buekens, 1995; Babushok, \& Tsang, 2003). The best technology of PCBs' degradation must not only provide a high degree of PCBs' destruction, but also must not lead to the formation of new toxic compounds (Kummling et al., 1997; Schwinkendorf et al., 1997; Rahuman et al., 2000). Possible combinations of PCBs' disposal operations depending on the source composition of the waste by Chetverykov et al. (2018) are presented in Figure 9.

It is advised to degrade concentrated PCB wastes by methods that do not require the use of additional components which may lead to the formation of new secondary toxic products. So, such results are provided by technologies grounded on the destruction of PCBs using special binding agents of degradation products. The same result can be provided by thermal methods, which do not use the additional heat-transfer medium (i.e. the products of the destruction are not supplemented by component of heat-transfer medium) that also can lead to the formation of secondary toxic products. Such thermal methods are the base of a wide range of plasma technology (Schwinkendorf et al., 1997; Rahuman et al., 2000).

If the composition of high concentrated PCB waste includes other components, and PCB extraction from waste matrix by solvents is not sufficiently effective, the thermal methods with products of oxidation of fossil fuels are used. The redox potential of such heat-transfer medium is regulated along the process chain, based on the criterion of minimum formation of secondary toxic compounds (Rahuman et al., 2000). Thus, all the technologies for the destruction of high concentrated PCBs could be conditionally split into 1) the technologies where destruction is achieved by using the appropriate reagents, and 2) the technologies with predominant use of thermal destruction. Group 2, in turn, is divided into technologies with chemically active or inert heat-transfer medium. In terms of economy, the destruction process in technologies using an additional heat-transfer medium is less costly than in technologies without it, but further treatment and neutralization of destruction products are more expensive in capital and in operating spending (Chetverykov et al., 2018). The end conclusions about the advantages and disadvantages of using a particular technology for treatment or disposal of high concentrated PCB waste can be made only by the calculated optimization of technology parameters coming from specific physical and chemical properties of the waste (Kummling et al., 1997). 


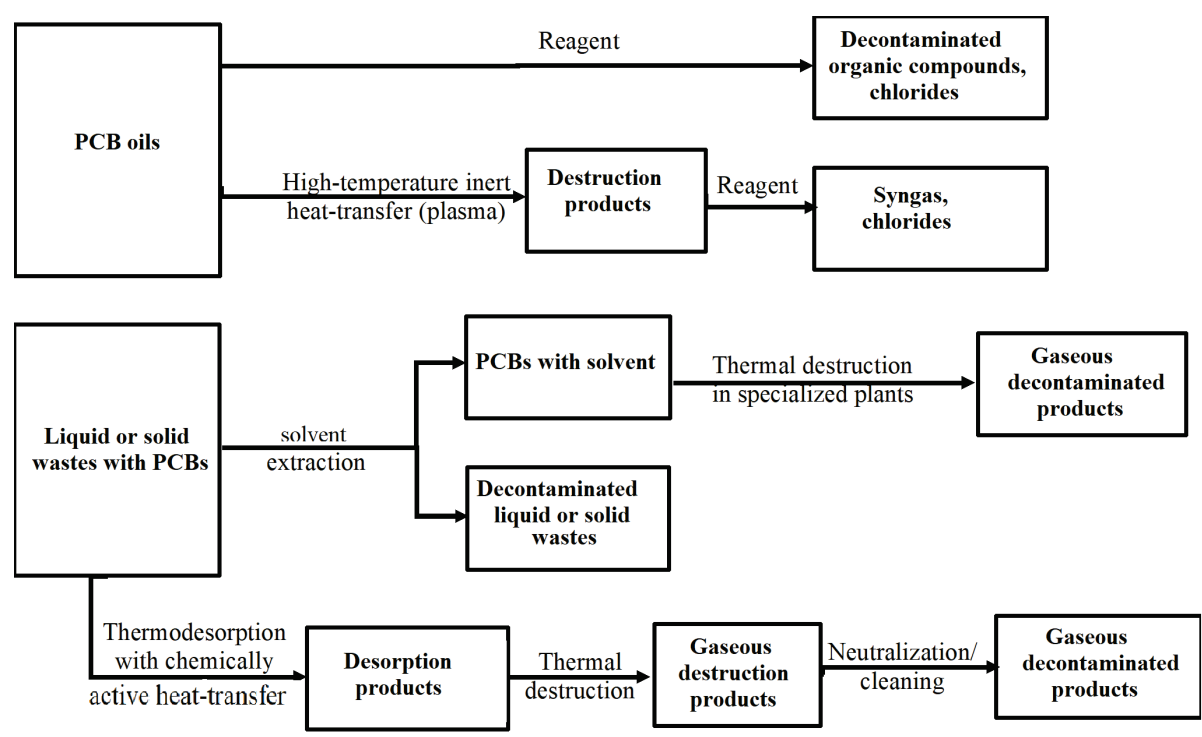

Fig. 9. The possible combinations of PCBs treatment operations depending on the initial composition of waste

Secretariats of the Stockholm and Basel conventions established the Working Groups conducted a number of workshops to identify the most effective methods of PCB waste treatment. The list of recommended methods is very large, so the following review presents those ones which are the most effective technical solutions for the efficiency of extraction/desorption, destruction and neutralization of chlorinated products. The set of operations to be undertaken for disposal of PCBs-containing wastes is determined by type of waste, contaminated with PCBs, content of PCBs in waste, presence of materials requiring some specific treatment methods, the need or possibility of waste reuse, etc. By conditions of implementation, all technologies of PCB treatment could be split into two groups: 1) on-site decontamination, without removal; 2) waste disposal and removal with further treatment in special plants. Methods of the group 1 are used mainly for the treatment of contaminated soil. The transformers containing PCBs can be treated "on-site", if there is a possibility of their reuse. Methods of waste treatment with removal to specialized facilities are used for all kinds of waste, containing PCBs. An environmentally friendly PCB disposal system should include optimal PCBs cleaning solutions. An overview of the methods and technologies for environmentally friendly PCB removal should begin with the cleanup of contaminated transformers. This will help to evaluate the volume and properties of PCBcontaining wastes generated from the purification of transformers, for which optimum disposal technologies should also be identified.

\section{Conclusions}

Toxic responses of PCBs are: acute lethality; body weight loss; carcinogenesis; dermal toxicity; fatty liver; genotoxicity; hepatomegaly; immunosuppressive effects; neurotoxicity; porphyria; reproductive and developmental toxicity; thymic atrophy; thyroid hormone-level alterations.

The most dangerous properties of PCBs for the environment are a persistent, high bioaccumulative availability, the ability to carry over long distances. Photodegradation of PCBs occurs in very limited quantities, the compounds are not hydrolysed and oxidized, and they are resistant to acids and alkalis and high temperature. PCBs are slow to biodegrade in the environment in comparison with many other organic chemicals and are generally persistent in all media. Since PCBs are lipophilic, they are very high bioaccumulative. Therefore, the level of PCBs in biota (especially in hydrobionts) is considered as one of the most important criteria of environmental pollution.

The most likely risks of PCBs contamination in Ukraine are in the areas of operation, repair or storage of electrical equipment. According the quantities of accumulated PCBs, leaders are Dnipropetrovsk (459 tons), Volyn (280 tons) and Kyivsk regions (255 tons). Today, Ukraine has made significant progress regarding the management of PCBs. A comprehensive approach to reducing the risk of PCBs for human health and the environment involves the improvement of the regulatory framework for managing in all stages of the toxicants' "life cycle". Obtaining complete and accurate information on the volumes and forms of PCBs accumulation and creation of modern effective technological support for PCBs degradation are a necessary part of Environmentally Sound Management of PCBs in Ukraine. The "PCBs Database in Ukraine" information system was created as a National PCBs Registry in Ukraine. It was designed to systematize, structure, and analyze in large sections the large amount of information collected during PCB inventorisation. All degradation technologies of highly concentrated PCBs are divided into technologies in which degradation is achieved predominantly by the use of appropriate reagents and technologies with a predominant use of thermal degradation. The best technology of PCBs degradation must not only provide a high degree of PCBs destruction, but also must not lead to the formation of new toxic compounds.

The authors are very grateful for the support of the GEF-UNIDO project "Environmentally sound management and final disposal of polychlorinated biphenyls (PCBs) in Ukraine".

\section{References}

Addink, R., \& Olie, K. (1995) Mechanisms for formation and destruction of polychlorinated dibenzo-p-dioxins and dibenzofurancs in heterogeneous systems. Environmental Science and Technology, 29, 1425-1435.

Babushok, V., \& Tsang, W. (2003). Gas-phase mechanism for dioxin formation. Chemosphere, 51, 1023-1029.

Bogdal, C., Muller, C., Buser, A., Wang, Z., Scheringer, M., \& Gerecke, A. (2014). Emissions of polychlorinated biphenyls, polychlorinated dibenzo-p-dioxins, and polychlorinated dibenzofurans during 2010 and 2011 in Zurich, Switzerland. Environment Science Technology, 48, 482-490.

Brix, A., Jokinen, M., Walker, N., Sells, D., \& Nyska, A. (2004). Characterization of bronchiolar metaplasia of the alveolar epithelium in female SpragueDawley rats exposed to 3,3',4,4',5-pentachlorobiphenyl (PCB 126). Toxicologic Pathology, 32(3), 333-337.

Cao, Y., Winneke, G., Wilhelm, M., Wittsiepe, J., Lemm, F., Fürst, P., Ranft, U., Imöhl, M., Kraft, M., Oesch-Bartlomowicz, B., \& Krämer, U. (2007). Environmental exposure to dioxins and polychlorinated biphenyls reduce levels of gonadal hormones in newborns: Results from the Duisburg cohort study. International Journal of Hygiene and Environmental Health, 211, 30-90.

Carlsson, P., Breivik, K., Brorström-Lundén, E., Cousins, I., Christensen, J., Grimalt, J., Halsall, C., Kallenborn, R., Abass, K., Lammel, G., Munthe, J., MacLeod, M., Odland, J., Pawlak, J., Rautio, A., Reiersen, L., Schlabach, M., Stemmler, I. Wilson, S., \& Wöhrnschimmel, H. (2018). Polychlorinated biphenyls (PCBs) as sentinels for the elucidation of Arctic environmental change processes: A comprehensive review combined with ArcRisk project results. Environment Science Pollution Results International, 25(23), 22499-22528.

Chen, P., \& Hsu, S. (1986). PCB poisoning from toxic rice-bran oil in Taiwan. In: Waid, J. (ed.). PCBs and the Environment. CRC Press, Michigan. 
Chetverykov, V., Koval, S., Rossoha, A., \& Bondar, O. (2018). Vyznachennja shljahiv ekologichno obgruntovanogo vydalennja PHD v Ukrajini [Guidelines on environmentally sound management and final disposal of polychlorinated biphenyls (PCBs)]. OLDI-PPUS, Kherson (in Ukrainian).

Cromwell, H., Johnson, A., McKnight, L., Horinek, M., Asbrock, C., Burt, S., Jolous-Jamshidi, B., \& Meserve, L. (2007). Effects of polychlorinated biphenyls on maternal odor conditioning in rat pups. Physiology \& Behavior, 91(5), 658-666.

Cummings, J., Nunez, A., \& Clemens, L. (2005). A cross-fostering analysis of the effects of PCB 77 on the maternal behavior of rats. Physiology and Behavior, 85(2), 83-91.

De Roos, A., Hartge, P., Lubin, J., Colt, J., Davis, S., Cerhan, J., Severson, R., Cozen, W., Patterson, D., Needham, L., \& Rothman, N. (2005). Persistent organochlorine chemicals in plasma and risk of non-Hodgkin's lymphoma. Cancer Rescues, 65(23), 11214-11226.

Diamond, M., Melymuk, L., Csiszar, S., \& Robson, M. (2010). Estimation of PCB stocks, emissions, and urban fate: Will our policies reduce concentrations and exposure? Environ Science Technology, 44, 2777-2783.

Dianyi, Y. (2014). Case studies in environmental medicine polychlorinated biphenyls (PCBs). Agency for Toxic Substances and Disease Registry, New York.

Faroon, O., \& Ruiz, P. (2011). Addendum to the toxicological profile for polychlorinated biphenyls. Atlanta.

Farrington, J., (2001). A risk-management strategy for PCB-contaminated sediments. National Academy Press, Washington.

Feshin, D., Komarova, K., Zheltov, V., Kalinkevich, G., Buhanko, N., Brodsky, E. (2006). Vlijanie kormov, zagrjaznennyh PHB, na organizm kur i cypljat [Effect of PCB contaminated feed on the body of chickens and hens]. Veterinary Medicine, 8, 48-52 (in Russian).

Feshin, D., Komarova, K., Zheltov, V., Brodsky, E., Kahnkevich, G., Shelepchikov, A., \& Boukhanko, N. (2005). Bioaccumulation and distribution of PCBs in hens and chickens. Organohalogen Compound, 67, 1498-1501.

Gasic, B., MacLeod, M., Klanova, J., Scheringer, M., Ilic, P., Lammel, G., Pajovic, A., Breivik, K, Holoubek, I., \& Hungerbühler, K. (2010). Quantification of sources of PCBs to the atmosphere in urban areas: A comparison of cities in North America, Western Europe and former Yugoslavia. Environmental Pollution, 158, 3230-3235.

Halse, A., Schlabach, M., Eckhardt, S., Sweetman, A., Jones, K., \& Breivik, K. (2011). Spatial variability of POPs in European background air. Atmospheric Chemistry and Physics, 11, 1549-1564.

Hardell, L., Bavel, B., Lindström, G., Carlberg, M., Dreifaldt, A., Wijkström, H., Starkhammar, H., Eriksson, M., Hallquist, A., \& Kolmert, T. (2003). Increased concentrations of polychlorinated biphenyls, hexachlorobenzene, and chlordanes in mothers of men with testicular cancer. Environmental Health Perspectives, 111(7), 930-934.

Hardell, L., Bavel, B., Lindström, G., Carlberg, M., Dreifaldt, A., Wijkström, H., Starkhammar, H., Eriksson, M., Hallquist, A., \& Kolmert, T. (2004). Concentrations of polychlorinated biphenyls in blood and the risk for testicular cancer. Intetnational Journal of Andrology, 27(5), 282-290.

Hardell, S., Tilander, H., Welfinger-Smith, G., Burger, J., \& Carpenter, D. (2010). Levels of polychlorinated biphenyls (PCBs) and three organochlorine pesticides in fish from the Aleutian Islands of Alaska. PLoS One, 5(8), e12396.

Heilmann, C., Grandjean, P., Weihe, P., Nielsen, F., \& Budtz-Jørgensen, E. (2006). Reduced antibody responses to vaccinations in children exposed to polychlorinated biphenyls. PLoS Medicine, 3(8), 1352-1359.

Hoffman, D., Melancon, M., Klein, P., Rice, C., Eisemann, J., Hines, R., Spann, J., \& Pendleton, G. (1996). Developmental toxicity of PCB 126 (3,3',4,4',5pentachlorobiphenyl) in nesting American kestrels (Falco sparverius). Fundamental and Applied Toxicology, 34(2), 188-200.

Huang, H., \& Buekens, A. (1995). On the mechanisms of dioxin formation in combustion processes. Chemosphere, 31, 4099-4117.

Hung, H., Katsoyiannis, A., Brorström-Lundén, E., Olafsdottir, K., Aas, W., Breivik, K., Bohlin-Nizzetto, P., Sigurdsson, A., Hakola, H., Bossi, R., Skov, H., Sverko, E., Barresi, E., Fellin, P., \& Wilson, S. (2016). Temporal trends of persistent organic pollutants (POPs) in arctic air: 20 years of monitoring under the arctic monitoring and assessment programme (AMAP). Environmental Pollution, $217,52-61$.
Kannan, K., Blankenship, A., Jones, P., \& Giesy, J. (2000). Toxicity reference values for the toxic effects of polychlorinated biphenyls to aquatic mammals. Human Ecological Risk Assessessment, 6(1), 181-201.

Khakhula, V., Karaulna, V., Bogatyr, L., Karpuk, L., Krikunova, O., \& Pavlichenko, A. (2018). Agroecological assessment of contamination of trophic chain components by persistent organic pollutants. Ukrainian Journal of Ecology, 8(2), $42-53$.

Kummling, K., Festarini, L., Woodland, S., Kornelsen, P., \& Hallett, D. (1997). An evaluation of levels of chlorinated aromatic compounds in ECO LOGIC process stack outputs. Organohalogen Compounds, 32, 66-71.

Kutsenko, S. (2003). Osnovy toksikologii [Fundamentals of toxicology]. Foliant, Saint Petersburg (in Russian)

Lee, D., Lee, I., Jin, S., Steffes, M., \& Jacobs, D. (2007). Association between serum concentrations of persistent organic pollutants and insulin resistance among nondiabetic adults: Results from the National Health and Nutrition Examination Survey 1999-2002. Diabetes Care, 30(3), 622-628.

Leonards, P. (1997). PCBs in mustelids. Analysis, food chain transfer and critical levels. Academisch Proefschrift, Amsterdam.

Macdonald, R., \& Bewers, J. (1996). Contaminants in the arctic marine environment: Priorities for protection. Journal of Marine Science, 53, 537-563.

Moklyachuk, L., Lishchuk, A., Yatsuk, I., \& Gorodyska, I. (2017). Zabrudnennia agroekosystem neprydatnymy pestycydamy jak regional'nyj indykator stanu zemel'nykh resursiv [Agricultural pollution by obsolete pesticides as a regional land resource indicator]. Balanced Nature Management, 2, 140-144 (in Ukrainian).

Mykhailenko, V., Safranov, T., \& Shanina, T. (2018). Analiz sytuaciji zi stijkymy organichnymy zabrudniuval'nymy rechovynamy v Ukrayini (na prykladi Odesy) [An analysis of the situation of persistent organic pollutants in Ukraine (by the example of Odessa)]. Visnyk of V. N. Karazin Kharkiv National University, Series Ecology, 18, 90-96 (in Ukrainian).

Nyska, A., Jokinen, M., Brix, A., Sells, D., Wyde, M., Orzech, D., Haseman, K., Flake, G., \& Walker, N. (2004). Exocrine pancreatic pathology in female Harlan Sprague-Dawley rats after chronic treatment with 2,3,7,8-tetrachlorodibenzo-pdioxin and dioxin-like compounds. Environmental Health Perspectives, 112(8), 903-909.

Park, H., Hertz-Picciotto, I., \& Petrik, J. (2008). Prenatal PCB exposure and thymus size at birth in neonates in Eastern Slovakia. Environmental Health Perspectives, 116(1), 104-109.

Rahuman, B., Pistone, L., Trifiro, F., \& Miertus, S. (2000). Destruction technologies for polychlorinated biphenyls (PCBs). ICS-UNIDO, Trieste.

Ritchie, J., Vial, S., Fuortes, L., Guo, H., Reedy, V., \& Smith, E. (2003). Organochlorines and risk of prostate cancer. Journal of Occupational and Environmental Medicine, 45(7), 692-702.

Safe, S. (1984). Polychlorinated biphenyls (PCBs) and polybrominated biphenyls (PBBs): Biochemistry, toxicology and mechanism of action. Critical Reviews in Toxicology, 13(4), 319-395.

Safe, S. (1994). Polychlorinated biphenyls (PCBs): Environmental impact, biochemical and toxic responses, and implications for risk assessment. Critical Reviews in Toxicology, 24(2), 87-149.

Schwinkendorf, W., Musgrave, B., \& Drake, R. (1997). Evaluation of alternative nonflame technologies for destruction of hazardous organic waste. MWFA, Idaho.

Seegal, R. (1996). Epidemiological and laboratory evidence of PCB-induced neurotoxicity. Critical Reviews in Toxicology, 26(6), 709-737.

Strang, C., Levine, S., Orlan, B., Gouda, T., \& Saner, W. (1984). High resolution of gas chromatographic analysis of cytochrome P-448 inducing PCB congeners in hazardous waste. Journal of Chromatography, 314, 482-487.

Tiedje, J., Quensen, J., Chee-Sanford, J., Schimel, J., \& Boyd, S. (1993). Microbial reductive dechlorination of PCBs. Biodegradation, 4(4), 231-240.

Walker, M., \& Peterson, R. (1994). Aquatic toxicity of dioxins and related chemicals. In: Schecter, A. (Ed.). (1994). Dioxins and health. Plenum, New York.

Weber, R. (2004). Relevance of PCDD/PCDF formation for the evaluation of POPs destruction technologies. - PCB destruction by super critical water oxidation (SCWO). Organohalogen Compounds, 66, 1263-1269.

Wöhrnschimmel, H., MacLeod, M., \& Hungerbuhler, K. (2013). Emissions, fate and transport of persistent organic pollutants to the Arctic in achanging global climate. Environmental Science Technology, 47, 2323-2330. 